\title{
A PCR-based Technique for Identification of Fusicoccum sp. from Pistachio and Various Other Hosts in California
}

\author{
Zhonghua Ma and Themis J. Michailides, Department of Plant Pathology, University of California Davis, Kear- \\ ney Agricultural Center, 9240 South Riverbend Ave., Parlier, CA 93648
}

\begin{abstract}
Ma, Z., and Michailides, T. J. 2002. A PCR-based technique for identification of Fusicoccum sp. from pistachio and various other hosts in California. Plant Dis. 86:515-520.

Botryosphaeria panicle and shoot blight of pistachio, caused by Fusicoccum sp. is a destructive disease in California. In this study, a pair of group-specific polymerase chain reaction (PCR) primers BDI and BDII, was developed for identification of Fusicoccum sp. from pistachio and other hosts in California based on the sequences of the rDNA internal transcribed spacer (ITS) region. The primers amplified a 356-bp DNA fragment for all 73 tested isolates of Fusicoccum sp. collected from pistachio and other hosts throughout California in different years, but not for the other 33 fungal species isolated from pistachio and the eight isolates of Fusicoccum sp. obtained from pistachio trees in Greece. The PCR assay using this pair of primers was sensitive enough to detect $5 \mathrm{pg}$ of genomic DNA of Fusicoccum sp. A simple DNA extraction procedure was developed that led to the rapid identification of Fusicoccum sp. from pistachio and other host plants in California.
\end{abstract}

Additional keywords: Botryosphaeria dothidea, nut disease, Pistacia vera

Botryosphaeria Ces. \& De Not. is a species-rich genus with a worldwide distribution and causes diseases of many woody plants. Species identification in Botryosphaeria is complicated and difficult because the teleomorphs of these fungi are rarely encountered in nature, and teleomorphic characteristics vary little among species. Furthermore, morphological characteristics of the anamorphs are also similar among some Botryosphaeria species and can be strongly influenced by the substrate on which they are produced (3). Additionally, difficulties in inducing sporulation of some Botryosphaeria species in culture have resulted in confusion relating to identification of Botryosphaeria species (21). Moreover, these fungi are not easily differentiated by host range because host range may be extensive, and fruiting structures of two to three Botryosphaeria spp. have been found together on a single host (9).

Botryosphaeria panicle and shoot blight of pistachio (Pistacia vera $\mathrm{L}$.) has become a major threat to California pistachio industry since the late 1980 s $(13,14)$. The pathogen causing panicle and shoot blight of pistachio was identified as the anamorph of $B$. dothidea, and referred to as a species of Dothiorella (14). However, Smith et al.

Corresponding author: T. J. Michailides

E-mail: themis@uckac.edu

Accepted for publication 27 December 2001.

Publication no. D-2002-0228-01R

(c) 2002 The American Phytopathological Society
(20) compared isolates of Fusicoccum sp. from pistachio with isolates of $B$. dothidea and $B$. ribis and found the pistachio isolates separated as a taxonomic clade that was between $B$. dothidea and B. ribis isolates. At the time when Michailides (14) identified the species causing Botryosphaeria panicle and shoot blight of pistachio, $B$. dothidea and $B$. ribis were considered synonymous (2). Currently, considerable controversy still exists surrounding the taxonomic status of $B$. dothidea and $B$. ribis. Some researchers regard the two species as synomyms, while others have treated them as separate taxa (21). Identification of Fusicoccum sp. from California pistachio is usually based on mycelial and pycnidiospore characteristics (14) since this pathogen has not been observed to produce sexual structures on artificial media and on pistachio (12). However, pseudothecia of $B$. dothidea were discovered in blighted shoots of pyracantha, olive, and blackberry grown next to infested pistachio orchards, and in avocado orchards in California (15). Production of pycnidiospores of Fusicoccum sp. isolates from pistachio requires 2 weeks. More importantly, identification of Fusicoccum sp. based on morphological characteristics requires an experienced observer. Thus, it is necessary to develop a simple, rapid, and reliable method for identification of Fusicoccum sp. from California pistachio.

Advances in molecular biology, particularly the polymerase chain reaction (PCR), have provided new opportunities for detection of plant pathogens. PCR with speciesspecific primers can provide a rapid and precise way to detect fungal plant patho- gens both in culture and in plant tissues. PCR assays may be based on DNA sequences of the internal transcribed spacer (ITS) region $(4,8,10,11,25)$, randomly amplified regions $(7,11,17)$, or speciesspecific repetitive sequences $(1,16)$. To date, a PCR-based technique has not been developed for identification of Fusicoccum sp. In previous studies (12, Z. Ma and T. J. Michailides, unpublished data), we observed a low level of genetic variation among the isolates of Fusicoccum sp. collected from pistachio and other host plants in California. This low genetic variation may allow us to develop molecular methodologies for detection of this pathogen. The objective of this study was to develop a reliable and simple PCR-based assay for the identification of Fusicoccum sp. from pistachio and other hosts in California.

\section{MATERIALS AND METHODS}

DNA sequences of ITS region and primer design. Five representative isolates (CE347, FP497, RE282, TP565, and WA373) of Fusicoccum sp. were differentiated by microsatellite-primed (MP)-PCR (Z. Ma, and T. J. Michailides, unpublished data) and selected for analysis of the sequences of the ITS region.

The ITS regions of these five isolates of Fusicoccum sp. were amplified using fungal universal primers ITS1 and ITS4 (24). PCR was performed in a $100-\mu l$ volume containing $10 \mathrm{ng}$ fungal genomic template, $1.0 \mu \mathrm{M}$ of each primer, $0.2 \mathrm{mM}$ of each dNTP, $2.0 \mathrm{mM} \mathrm{MgCl} 2$, 1× Taq Buffer and 1.5 U of Taq Polymerase (Promega, Madison, WI). The PCR was performed using the following parameters: an initial preheat for $3 \mathrm{~min}$ at $95^{\circ} \mathrm{C}$, followed by 35 cycles of denaturation at $94^{\circ} \mathrm{C}$ for $1 \mathrm{~min}$, annealing at $58^{\circ} \mathrm{C}$ for $1 \mathrm{~min}$, extension at $72^{\circ} \mathrm{C}$ for $1.5 \mathrm{~min}$, and terminated with a final extension at $72^{\circ} \mathrm{C}$ for $10 \mathrm{~min}$. The PCR products were verified on a $1.5 \%$ agarose gel in Triacetate (TAE) buffer. The amplifications were purified using the QIAquick PCR Purification Kit (QIAGEN Inc., Valencia, CA) and sequenced by DBS Sequencing Inc. (Division of Biological Sciences, University of California at Davis). The ITS sequences of other related Botryosphaeria species (B. corticis, B. obtusa, B. parva, B. ribis, $B$. stevensii, and $F$. luteum) were obtained from GenBank databases.

The complete sequences of the ITS regions (ITS1, 5.8S gene, and ITS2) of Fusicoccum sp. isolates CE347, FP497, RE282, TP565, WA373 (GenBank Acces- 
sion Nos. AF452701 - AF452705), and using the computer program Clustal W 1.81 (European Bioinformatics Institute, Cambridge, UK). A pair of primers (BDI and BDII) specifically targeting Fusicoccum sp. rDNA (Fig. 1) was constructed using a computer program, Web Primers (http://alces.med.umn.edu/webprimers.htm 1). The primers were synthesized by Invitrogen (Life Technologies, Grand Island, NY).

Specificity and sensitivity of primers BDI and BDII. Other hosts of Fusicoccum sp. can serve as potential inoculum sources for pistachio. Isolates of Fusicoccum sp. from pistachio and other host plants in California are related genetically (12). In this study, 73 isolates of Fusicoccum sp. collected from pistachio and other hosts throughout California in different years, as well as eight isolates of Fusicoccum sp. collected from pistachio trees in Greece, and 33 different fungal species associated with pistachio were used for specificity tests (Table 1). The morphological identification of Fusicoccum sp. isolates was based on the characteristics of mycelia growing on potato dextrose agar (PDA, Microtech Scientific, Orange, CA) and pycnidiospores produced on autoclaved pistachio leaves (12). The isolates of other species were identified based on standard morphological characteristics. Fungal genomic DNA of each isolate was extracted using FastDNA Kit (BIO 101, Vista, CA). In sensitivity tests, serial amounts of genomic DNA (50 fg to $5 \mathrm{ng}$ ) of the Fusicoccum sp. isolates FP497, TP565, and CE347 were used as DNA template for PCR amplifications.

The PCR reaction was performed in a $50-\mu$ l volume containing $5 \mu$ (approximately $15 \mathrm{ng}$ ) fungal genomic DNA extracted by FastDNA Kit, $0.2 \mu \mathrm{M}$ of each primer (BDI and BDII), $0.2 \mathrm{mM}$ of each dNTP, $2.0 \mathrm{mM} \mathrm{MgCl}_{2}$, 1× Promega Taq Polymerase Buffer and 1.5 U of Promega Taq Polymerase. The PCR was performed using the following parameters: an initial preheat for $3 \mathrm{~min}$ at $95^{\circ} \mathrm{C}$, followed by 35 cycles of denaturation at $94^{\circ} \mathrm{C}$ for $1 \mathrm{~min}$, annealing at $69^{\circ} \mathrm{C}$ for $1 \mathrm{~min}$, extension at $72^{\circ} \mathrm{C}$ for $1.5 \mathrm{~min}$, and terminated with a other related fungal species were aligned

final extension at $72^{\circ} \mathrm{C}$ for $10 \mathrm{~min}$. PCR products $(10 \mu$ per sample) were verified on $1.5 \%$ agarose gels in TAE buffer.

MP-PCR fingerprinting for the isolates of Fusicoccum sp. collected from pistachio trees in California and Greece. Eight isolates from Greece, as well as 11 California isolates selected randomly, were used for analysis of DNA fingerprinting produced by the microsatellite primer M13 (GAG GGT GGC GGT TCT), $\mathrm{T}_{3} \mathrm{~B}$ (AGG TCG CGG GTT CGA ATC C), or $(\mathrm{CTC})_{4} \mathrm{RC}$. The PCR reactions were performed in 50- $\mu$ l volume containing: $50 \mathrm{ng}$ fungal genomic template, $1.0 \mu \mathrm{M}$ of microsatellite primer, $0.2 \mathrm{mM}$ of each dNTP, $2.0 \mathrm{mM} \mathrm{MgCl} 2,1 \times$ Promega Taq Polymerase Buffer (10 mM Tris-Cl, pH 9.0, 50 $\mathrm{mM} \mathrm{KCl}, 0.1 \%$ Triton X-100) and $1.5 \mathrm{U}$ of Promega Taq Polymerase. The PCR was performed using the following parameters: an initial preheat for $3 \mathrm{~min}$ at $95^{\circ} \mathrm{C}$, followed by 40 cycles of denaturation at $94^{\circ} \mathrm{C}$ for $1 \mathrm{~min}$, annealing at $50^{\circ} \mathrm{C}$ for $1 \mathrm{~min}$, extension at $72^{\circ} \mathrm{C}$ for $1.5 \mathrm{~min}$, and terminated with a final extension at $72^{\circ} \mathrm{C}$ for 10 min. The PCR products ( $10 \mu$ l per sample) were separated on $1.5 \%$ agarose gels in TAE buffer and photographed after staining with ethidium bromide.

Rapid extraction of DNA for identification of Fusicoccum sp. To rapidly identify isolates of Fusicoccum sp., approximately $20 \mathrm{mg}$ (fresh weight) of mycelia were collected by gently scraping the surface of a 3-day-old culture on PDA with a sterilized loop and placed in a $1.5-\mathrm{ml} \mathrm{mi-}$ crocentrifuge tube containing $100 \mu$ of 1 M Tris-HCl (pH 8.0). Samples were boiled at $98^{\circ} \mathrm{C}$ for $15 \mathrm{~min}$ and immediately placed on ice for $5 \mathrm{~min}$. A 5- $\mu \mathrm{l}$ aliquot of a 1:10 or 1:100 dilution of resulting supernatant was used for PCR amplification.

Double-blind test. Ten isolates of Fusicoccum species that were similar in colony morphology on PDA were used for a double-blind test. Extraction of DNA was conducted using the method of boiling mycelia described above. A 5- $\mu$ l aliquot of a 1:10 supernatant dilution of each isolate was used for PCR amplification with the primers BDI and BDII. To identify these isolates based on the characteristics of pycnidiospores, mycelial plugs of each

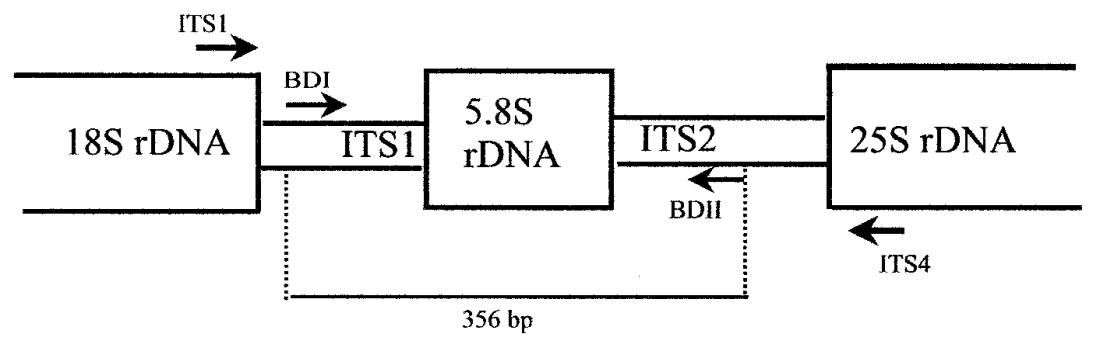

Fig. 1. Schematic presentation of locations of the pair of group-specific polymerase chain reaction (PCR) primers (BDI and BDII) developed from the sequences of the rDNA internal transcribed spacer (ITS) region for identification of Fusicoccum sp. from pistachio and other hosts in California. The primers ITS1 and ITS4 are the universal primers. isolate were transferred on autoclaved pistachio leaves that were placed on the surface of agar in plates supplemented with $5 \mathrm{ml}$ of $2 \%$ agar in the bottom (12). After incubation under light at room temperature $\left(25 \pm 2^{\circ} \mathrm{C}\right)$ for 2 weeks, mature pycnidia were produced on pistachio leaves, and the characteristics of pycnidiospores for each isolate were examined under a light microscope.

Detection of Fusicoccum sp. from natural infected pistachio leaves. During the 2001 growing season, 20 pistachio leaves showing putative incipient infections of Fusicoccum sp. were collected from an orchard at the Kearney Agricultural Center, University of California in Parlier. A small piece of tissue $(0.5 \times 0.5$ $\mathrm{cm})$ was taken from the margin of each infection point and surface-disinfested with $0.525 \%$ sodium hypochlorite for $3 \mathrm{~min}$ (10\% commercial bleach), rinsed with sterile water, and placed on acidified (2.5 $\mathrm{ml}$ of $25 \% \mathrm{vol} / \mathrm{vol}$ lactic acid per liter) potato dextrose agar (APDA, Microtech Scientific). After incubation at $30^{\circ} \mathrm{C}$ for 4 days, approximately $10 \mathrm{mg}$ (fresh weight) of mycelia were collected and placed in a 1.5-ml microcentrifuge tube containing 50 $\mu \mathrm{l}$ of $1 \mathrm{M}$ Tris- $\mathrm{HCl}(\mathrm{pH} \mathrm{8.0)}$ ). Extraction of DNA was conducted using the boiling method described above. A 5- $\mu$ l aliquot of a 1:10 dilution of each sample was used for PCR amplification using the primers BDI and BDII. Morphological identification of Fusicoccum sp. from these samples was performed according to the protocol described above.

\section{RESULTS}

Primers design for Fusicoccum sp. Sequences from the ITS regions obtained from five isolates of Fusicoccum sp. collected from pistachio and other hosts in California were very similar (99.6\% identical). A pair of primers specifically targeting the Fusicoccum sp. ITS region was designed as BDI (5'-CTC GAC TCT CCC ACC CTA TGT-3') and BDII (5'-GAG GTG TTT TCT ACT ACG CTC GA-3') (Fig. 1). This pair of primers amplified a 356-bp DNA fragment from the isolates CE347, FP497, RE282, TP565, and WA373 of Fusicoccum sp.

Specificity and sensitivity of the primers BDI and BDII. Using a high annealing temperature $\left(69^{\circ} \mathrm{C}\right)$, a 356-bp DNA fragment was amplified consistently from all 73 tested Fusicoccum sp. isolates collected from pistachio and other hosts throughout California in different years, but not from 33 other fungal species isolated from pistachio trees in California and the eight isolates of Fusicoccum sp. collected from pistachios in Greece (Table 1). The eight isolates of Fusicoccum sp. collected from pistachio trees in Greece were significantly different from the California isolates in DNA fingerprinting produced by MP-PCR (Fig. 2). Examples of PCR products ampli- 
fied from genomic DNA of various fungal species by the primers BDI and BDII are presented in Figure 3.

In a sensitivity test with serial DNA dilutions of three Fusicoccum sp. isolates FP497, TP565, and CE347, the primers BDI and BDII were effective at detecting five pg of fungal genomic DNA. Examples of PCR products amplified from genomic
DNA of the isolate FP497 using the primers BDI and BDII are presented in Figure 4.

PCR with DNA from the rapid extraction procedure. DNA from boiling mycelial supernatant was suitable for PCR amplification. Using either $1: 10$ or $1: 100$ aliquot dilution of supernatant obtained by boiling $20 \mathrm{mg}$ mycelia in $100 \mu \mathrm{l} 1 \mathrm{M}$ Tri-
$\mathrm{HCl}$, the primers BDI and BDII yielded the expected amplification product (356 bp) for each of four tested Fusicoccum sp. isolates (Fig. 5).

Double-blind test. After 4 days of incubation on PDA, 10 tested isolates were very similar in colony morphology. However, the PCR assay showed 6 of 10 isolates to be Fusicoccum sp. These six iso-

Table 1. List of the isolates of Fusicoccum sp. and other fungal species isolated from pistachio and other hosts used in this study

\begin{tabular}{|c|c|c|c|c|}
\hline Species & Isolate & Host & Location & PCR assay ${ }^{z}$ \\
\hline Fusicoccum sp. & MP1, MP2, MP3, MP4, MP14 & Pistachio & Montgomery, Butte County & + \\
\hline Fusicoccum sp. & $\mathrm{CP} 2, \mathrm{CP} 3, \mathrm{CP} 5, \mathrm{CP} 6$ & Pistachio & Chico, Butte County & + \\
\hline Fusicoccum sp. & HP7, HP8, HP10, HP13 & Pistachio & Hansen, Glenn County & + \\
\hline Fusicoccum sp. & SP 81, SP132, SP133, SP200 & Pistachio & San Joaquin County & + \\
\hline Fusicoccum sp. & KP 94, КР95, КР96, КР97 & Pistachio & Kings County & + \\
\hline Fusicoccum sp. & MAP103, MAP106, MAP108, MAP111 & Pistachio & Madera County & + \\
\hline Fusicoccum sp. & BP169, BP170, BP171, BP172 & Pistachio & Butte County & + \\
\hline Fusicoccum sp. & FP497, FP498, FP499, FP579, FP624, FP719 & Pistachio & Fresno County & + \\
\hline Fusicoccum sp. & ТР565, ТР566, ТР567, ТР764, ТР766 & Pistachio & Tulare County & + \\
\hline Fusicoccum sp. & AGP116, AGP118, AGP123, AGP124 & Pistachio & Aegina, Greece & - \\
\hline Fusicoccum sp. & TGP128, TGP129, TGP130, TGP131 & Pistachio & Thessaloniki, Greece & - \\
\hline Fusicoccum sp. & AV8, AV10 & Avocado & Riverside City & + \\
\hline Fusicoccum sp. & CE347, CE348, CE403, CE412 & Cedar & Fresno County & + \\
\hline Fusicoccum sp. & EU353, EU356, EU402 & Eucalyptus & Fresno County & + \\
\hline Fusicoccum sp. & JA358 & Jasmine & McCall, Fresno County & + \\
\hline Fusicoccum sp. & JU38, JU39, JU40, JU394, JU395 & Juniper & Clovis, Fresno County & + \\
\hline Fusicoccum sp. & PE361 & Pear & Stockton, San Joaquin County & + \\
\hline Fusicoccum sp. & RA363 & Raywood ash & Clovis, Fresno County & + \\
\hline Fusicoccum sp. & RE276, RE279, RE365 & Redwood & Reedley, Fresno County & + \\
\hline Fusicoccum sp. & RE282, RE288 & Redwood & Madera County & + \\
\hline Fusicoccum sp. & RE289, RE290, RE291, RE292 & Redwood & Hanford, Kings County & + \\
\hline Fusicoccum sp. & WA370, WA372, WA373 & Walnut & Fresno County & + \\
\hline Fusicoccum sp. & WA371 & Walnut & Los Banos, Madera County & + \\
\hline Fusicoccum sp. & WA389 & Walnut & San Joaquin County & + \\
\hline Fusicoccum sp. & WA408, WA409 & Walnut & Merced County & + \\
\hline Alternaria alternata & $\mathrm{CH} 1$ & Pistachio & Fresno County & - \\
\hline Aspergillus ochraceus & 2568 & Pistachio & Colusa County & - \\
\hline A. parasiticus & 2535 & Pistachio & San Joaquin County & - \\
\hline A. terreus & 2570 & Pistachio & Colusa County & - \\
\hline Bipolaris spicifera & $\mathrm{CH} 2$ & Pistachio & Glenn County & - \\
\hline Botryosphaeria obtusa & 307 & Pistachio & Fresno County & - \\
\hline B. obtusa & 308 & Apple & Fresno County & - \\
\hline B. obtusa & 309 & Apple & Fresno County & - \\
\hline B. obtusa & 312 & Apple & San Joaquin County & - \\
\hline B. rhodina & 315 & Pistachio & Stanislaus County & - \\
\hline Botrytis cinerea & 549 & Pistachio & Fresno County & - \\
\hline Cladosporium cladosporioides & 1887 & Pistachio & Fresno County & - \\
\hline Curvularia inaequalis & $\mathrm{CH} 3$ & Pistachio & Glenn County & - \\
\hline C. lunata & $\mathrm{CH} 4$ & Pistachio & San Joaquin County & - \\
\hline Chaetomium sp. & $\mathrm{CH} 5$ & Pistachio & Yolo County & - \\
\hline Drechslera biseptata & $\mathrm{CH} 6$ & Pistachio & San Joaquin County & - \\
\hline Emericella sp. & 2536 & Pistachio & Glenn County & - \\
\hline Epicoccum purpurascens & $\mathrm{CH} 7$ & Pistachio & Glenn County & - \\
\hline Exserohilum rostrata & $\mathrm{CH} 22$ & Pistachio & Glenn County & - \\
\hline Fusarium acuminatum & $\mathrm{CH} 8$ & Pistachio & San Joaquin County & - \\
\hline F. culmorum & CH9 & Pistachio & Yolo County & - \\
\hline F. moniliforme & $\mathrm{CH} 10$ & Pistachio & Glenn County & - \\
\hline F. dimerum & CH11 & Pistachio & Glenn County & - \\
\hline Humicola grisea & CH12 & Pistachio & San Joaquin County & - \\
\hline Monilia sp. & 608 & Pistachio & $\ldots$ & - \\
\hline Mucor sp. & 2541 & Pistachio & Tulare County & - \\
\hline Nigrospora sp. & CH13 & Pistachio & Glenn County & - \\
\hline Paecilomyces lilacinus & $\mathrm{CH} 14$ & Pistachio & Yolo County & - \\
\hline Penicillium expansum & CH15 & Pistachio & San Joaquin County & - \\
\hline P. chrysogenum & $\mathrm{CH} 16$ & Pistachio & Glenn County & - \\
\hline Phomopsis sp. & $\mathrm{CH} 17$ & Pistachio & Yolo County & - \\
\hline Rhizoтисог sp. & 1886 & Pistachio & Kings County & - \\
\hline Stemphylium botryosum & CH18 & Pistachio & Glenn County & - \\
\hline Torula sp. & CH19 & Pistachio & San Joaquin County & - \\
\hline Trichoderma sp. & $\mathrm{CH} 20$ & Pistachio & Glenn County & - \\
\hline Ulocladium atrum & $\mathrm{CH} 21$ & Pistachio & San Joaquin County & - \\
\hline
\end{tabular}

${ }_{\mathrm{z}}+$ denotes that the primer pair BDI and BDII yielded the expected amplification product ( $356 \mathrm{bp}$ ) from the isolate, and - denotes that the primers did not amplify the product from the isolate. 
lates were also confirmed as Fusicoccum sp. based on the characteristics (hyaline, nonseptate) of pycnidiospores produced on autoclaved pistachio leaves after 2 weeks of incubation at room temperature. The other four isolates were identified as $B$. obtusa based on pycnidiospore characteristics (dark, nonseptate spores).

Detection of Fusicoccum sp. from naturally infected pistachio leaves. Identification of Fusicoccum sp. from putative incipient infected pistachios based on PCR assay was in agreement with the morphological identification. After 4 days of incubation on APDA plates, mycelial cultures were initiated from 16 of 20 leaf samples. PCR assay of 16 mycelial samples showed that 14 of 16 samples were identified as Fusicoccum sp. These 14 of 16 mycelial samples were further confirmed as Fusicoccum sp. based on the characteristics of pycnidiospores produced on autoclaved pistachio leaves after 2 weeks of incubation.

\section{DISCUSSION}

In this study, a pair of group-specific PCR primers, BDI and BDII, was developed based on ITS sequences for identification of Fusicoccum sp. from pistachio

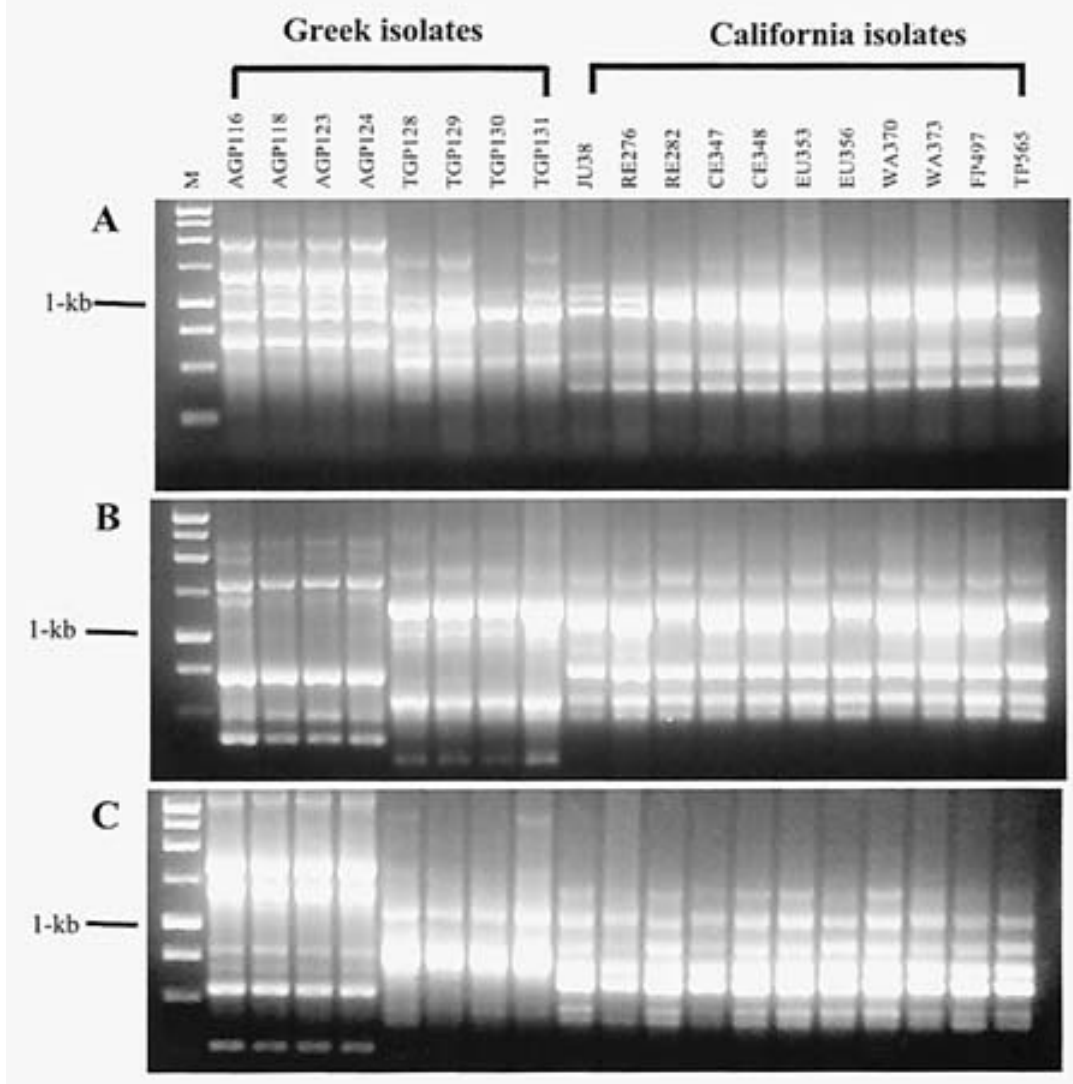

Fig. 2. Comparisons of DNA fingerprinting produced by microsatellite primer A, M13, B, $\mathrm{T}_{3} \mathrm{~B}$, and C, (CTC) $)_{4} \mathrm{RC}$ among isolates of Fusicoccum sp. colleted from pistachio in California and Greece. M is a molecular weight marker (1-kb DNA ladder, Promega, Madison, WI).

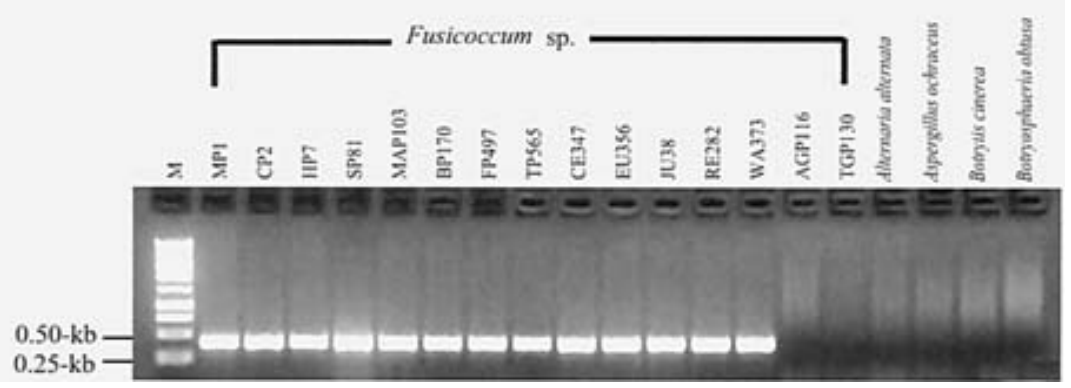

Fig. 3. Specificity of the primer pair BDI and BDII, which amplified a 356-bp fragment from the genomic DNA of the isolates of Fusicoccum sp. collected from pistachio and other hosts throughout California. The primers did not amplify the expected polymerase chain reaction product from other fungal species isolated from pistachio and from the isolates of Fusicoccum sp. collected from pistachio trees in Greece (such as AGP116 and TGP130). M is a molecular weight marker (1-kb DNA ladder, Promega, Madison, WI).

and other host plants in California. The primers were capable of identifying all 73 tested Fusicoccum sp. isolates collected from pistachio and other hosts throughout California in different years (Table 1), but they did not amplify the expected DNA fragment from the eight isolates of Fusicoccum sp. obtained from pistachios in Greece. This result is further supported by the DNA fingerprinting tests, in which the eight isolates from Greece were significantly different from the isolates obtained from pistachio and other host plants in California (Fig. 2). Similar group-specific primers were also reported on other pathogens $(7,10)$. Several distinct ITS groups have been reported for isolates of Fusicoccum sp. collected from different locations $(5,9,21$, Z. Ma and T. J. Michailides, unpublished data). Thus, it may be very difficult to develop a pair of PCR primers just based on ITS sequences to identify all the isolates of this pathogen worldwide.

The PCR-based technique has advantages over the traditional culture methods used for identification of Fusicoccum sp. Unlike culture methods that require experience in identification of Fusicoccum species, the PCR-based method is easy to learn and can provide reliable results, even when persons who conduct these tests have no previous experience with this pathogen. Additionally, the results of identification of Fusicoccum sp. based on morphological characteristics can be influenced strongly by the substrate on which the fungus was grown (3). However, the PCR-based identification should not be affected by the substrate on which the pathogen grows. Finally, the PCR-based identification of Fusicoccum sp. may be performed as soon as there is sufficient fungal material (10 $\mathrm{mg}$ fresh weight) without the need to wait 2 weeks for the formation of mature pycnidia and pycnidiospores. Thus, the PCR-based assay presented in this study should be a useful method for identification of Fusicoccum sp. from pistachio and other hosts in California, especially for those researchers who do not have enough experience with Fusicoccum species. Recently, this PCR-based technique has been used for identification of a number of isolates of Fusicoccum sp. collected from commercial pistachio orchards in various counties in California (N. Ntahimpera and T. J. Michailides, unpublished data).

Most PCR procedures used for detection of plant pathogens are based on lengthy DNA extraction protocols (6). In this study, we successfully extracted DNA for PCR amplification by boiling mycelia of Fusicoccum sp. The boiling extraction protocol worked with both pure and contaminated cultures. Similar extraction protocols have been reported on Eutypa lata (11), Gremmeniella abietina (8), and Phoma tracheiphila (18). In some cases, the boiling method was also used for extraction of DNA directly from infected 
plant tissues $(8,11)$, although it did not work with latent infections on pistachio leaves in this study.

In this study, an attempt to use PCR assay for directly detecting latent infections of Fusicoccum sp. on pistachio tissue was not successful. This was probably because of inhibitors that normally affect PCR assays by inhibiting the Taq polymerase. The PCR inhibitors may have prevented the primer pair BDI and BDII from amplifying the fungal genomic DNA (10 pg) mixed with the DNA extracts of infected pistachio leaves, although the primers were sensitive enough to detect five pg of fungal genomic DNA suspended in water (Fig. 4). Reports have been made on inhibitors from other plant pathogens interfering with PCR assays $(7,10,11,17,25)$. To overcome PCR inhibitors, we used: (i) the hexadecyltrimethylammonium bromide (CTAB) method, (ii) the BIO101 FastDNA Kit method, (iii) the method of boiling infected plant tissues (11), and (iv) the $\mathrm{NaOH}$ extraction method (23) to extract DNA from pistachio tissues with incipient infections by Fusicoccum sp. However, all these tests were unsuccessful.

Several studies showed that increase of overcome the effects of inhibitors $(17,19,22)$. In this study, the PCR assay was also successful and reliable in identifungal biomass by preincubation could

fying the isolates of Fusicoccum sp. from naturally infected pistachio tissues after 4 days of preincubation on APDA. However, further experiments will be needed to improve the PCR assay so that the technique can directly detect Fusicoccum sp. on pistachio and other host plants in California.

\section{ACKNOWLEDGMENTS}

This research was supported in part by grants from California Pistachio Commission and the University of California BioSTAR Project. We thank Wei-qun Chen for providing some isolates of other fungal species recovered from pistachio, and George F. Driever for reviewing the manuscript prior to submission.

\section{LITERATURE CITED}

1. Boehm, E. W. A., Ma, Z., and Michailides, T. J. 2001. Species-specific detection of Monilinia fructicola from California stone fruits and flowers. Phytopathology 91:428-439.

2. Brown, E. A., II, and Britton, K. D. 1986. Botryosphaeria disease of apple and peach in the southeastern United States. Plant Dis. 70:480-484.

3. Butin, H. 1993. Morphological adaptation and spore pleomorphism in the form-complex $D i$ chomera-Camarosporium and FusicoccumDothiorella. Sydowia 45:161-166.

4. Cam, B. L., Devaux, M., and Parisi, L. 2001. Specific polymerase chain reaction identification of Venturia nashicola using internally transcribed spacer region in the ribosomal DNA. Phytopathology 91:900-904.

5. Denman, S., Crous, P. W., Taylor, J. E., Kang, J., Pascoe, I., and Wingfield, M. J. 1999. An overview of the taxonomic history of Bot-

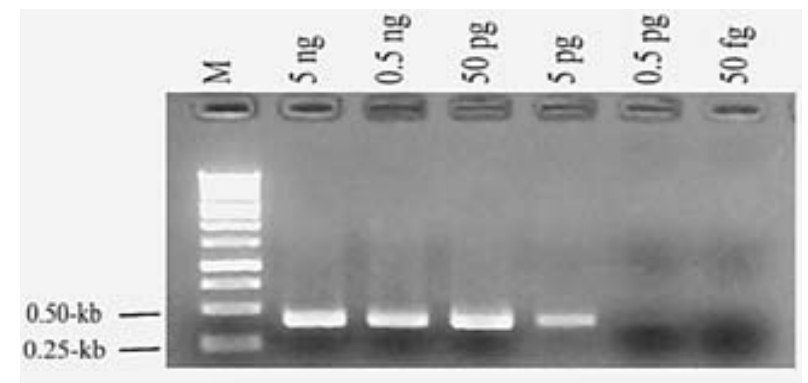

Fig. 4. Sensitivity of the primer pair BDI and BDII. Polymerase chain reaction amplification of serial amounts of genomic DNA (50 fg to $5 \mathrm{ng}$ ) from the Fusicoccum sp. isolate FP497 collected from pistachio in California. M is a molecular weight marker (1-kb DNA ladder, Promega, Madison, WI).

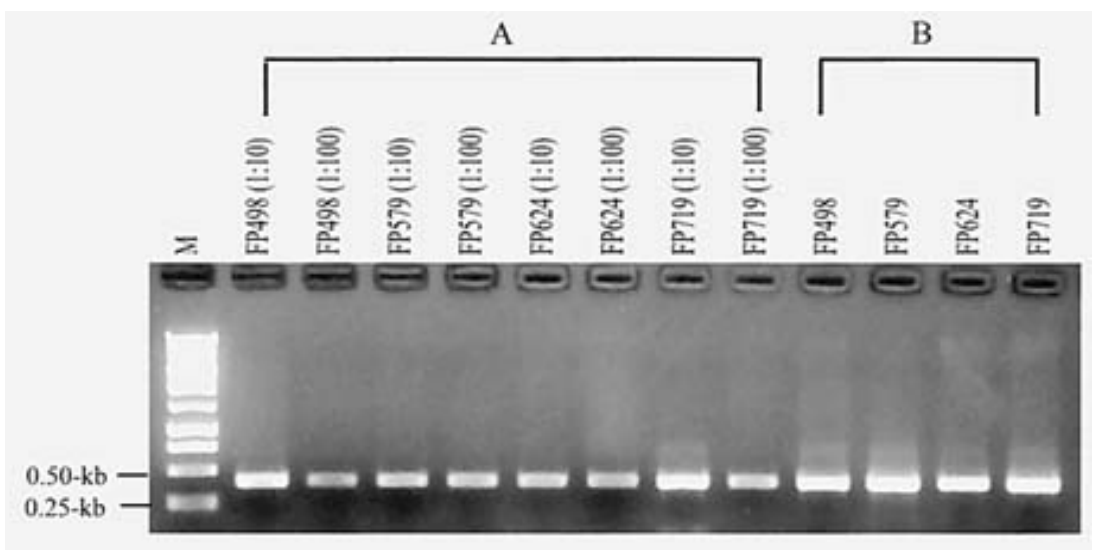

Fig. 5. PCR amplification of genomic DNA of four pistachio isolates (FP498, FP579, FP624, and FP719) of Fusicoccum sp. extracted by A, boiling mycelia (1:10 or 1:100 supernatant dilutions), and B, FastDNA Kit (BIO 101, Vista, CA) (1 $\mu \mathrm{l}$ of DNA extraction per reaction). M is a molecular weight marker (1-kb DNA ladder, Promega, Madison, WI). ryosphaeria and a re-evaluation of its anamorphs based on morphology and ITS rDNA phylogeny. Sydowia 52:129-140.

6. Faggian, R., Bulman, S. R., Lawrie, A. C., and Porter, I. J. 1999. Specific polymerase chain reaction primers for the detection of Plasmodiophora brassicae in soil and water. Phytopathology 89:392-397.

7. Guzmán, P., Gepts, P., Temple, S., Mkandawire, A. B. C., and Gilbertson, R. L. 1999 Detection and differentiation of Phaeoisariopsis griseola isolates with the polymerase chain reaction and group-specific primers. Plant Dis. 83:37-42.

8. Hamelin, R. C., Bourassa, M., Rail, J., Dusabenyagasani, M., Jacobi, V., and Laflamme, G. 2000. PCR detection of Gremmeniella abietina, the causal agent of Scleroderris canker of pine. Mycol. Res. 104:527-532.

9. Jacobs, K. A., and Rehner, S. A. 1998. Comparisons of cultural and morphological characters and ITS sequences in anamorphs of Botryosphaeria and related taxa. Mycologia 90:601-610.

10. Kageyama, K. Ohyama, A., and Hyakumachi, M. 1997. Detection of Pythium ultimum using polymerase chain reaction with group-specific primers. Plant Dis. 81:1155-1160.

11. Lecome, P., Péros, J. P., Blancard, D., Bastien, N., and Délye, C. 2000. PCR assays that identify the grapevine dieback fungus Eutypa lata. Appl. Environ. Microbiol. 66:4475-4480.

12. Ma, Z., Boehm, E. W. A., Luo, Y., and Michailides, T. J. 2001. Population structure of Botryosphaeria dothidea from pistachio and other hosts in California. Phytopathology 91:665-672.

13. Ma, Z., Morgan, D. P., and Michailides, T. J. 2001. Effects of water stress on Botryosphaeria blight of pistachio caused by Botryosphaeria dothidea. Plant Dis. 85:745-749.

14. Michailides, T. J. 1991. Pathogenicity, distribution, sources of inoculum, and infection courts of Botryosphaeria dothidea on pistachio. Phytopathology 81:566-573.

15. Michailides, T. J., Morgan, D. P., and Felts, D. 2001. Collection and characterization of Botryosphaeria dothidea from various hosts and pathogenicity studies on pistachio. Kearney Agricultural Center Plant Protection Quarterly 11 (1):3-8.

16. Plyler, T. R., Simone, G. W., Fernandez, D. and Kistler, H. C. 1999. Rapid detection of the Fusarium oxysporum lineage containing the Canary Island date palm with pathogen. Phytopathology 89:407-413.

17. Pryor, B., and Gilbertson, R. L. 2001. A PCRbased assay for detection of Alternaria radicina on carrot seed. Plant Dis. 85:18-23.

18. Rollo, F., Salvi, R., and Torchia, P. 1990. Highly sensitive and fast detection of Phoma tracheiphila by polymerase chain reaction. Appl. Microbiol. Biotechnol. 32:572-576.

19. Schaad, N. W., Cheong, S. S., Tamaki, S., Hatziloukas, E., Panopoulos, N. J. 1995. A combined biological and enzymatic amplification (BIO-PCR) technique to detect Pseudomonas syringae pv. phaseolicola in bean seed extracts. Phytopathology 85:243-248.

20. Smith, D. R., Michailides, T. J., and Stanosz, G. R. 2001. Differentiation of a Fusicoccum species causing panicle and shoot blight on California pistachio trees from Botryosphaeria dothidea. Plant Dis. 85:1235-1240.

21. Smith, H., Crous, P. W., Wingfield, M. J., Coutinho, T. A. and Wingfield B. D. 2001. Botryosphaeria eucalyptorum sp. nov., a new species in the B. dothidea-complex on Eucalyptus in South Africa. Mycologia 93:277285.

22. Taylor, J. L. 1993. A simple, sensitive, and rapid method for detection of seed contaminated with highly virulent Leptosphaeria 
maculans. Appl. Environ. Microbiol. 59:36813685.

23. Wang, H., Meiqing, Q., and Cutler, A. J. 1993. A simple method of preparing plant samples for PCR. Nucleic Acids Res. 21:4153-4154.

24. White, T. J., Bruns, T., Lee S., Taylor, J. 1990.
Amplification and direct sequencing of fungal ribosomal RNA genes for phylogenetics. Pages 315-322 in: PCR Protocols: A Guide to Methods and Applications. Academic Press,

San Diego.

25. Zhang, A. W., Hartman, G. L., Ricconi, L.,
Chen, W. D., Ma, R. Z., and Pedersen, W. L. 1997. Using PCR to Distinguish Diaporthe phaseolorum and Phomopsis longicolla from other soybean fungal pathogens and to detect them in soybean tissues. Plant Dis. 81:11431149 